\title{
A SIMPLE ESTIMATION OF SALICYLATE IN SERUM
}

\author{
BY
}

\author{
A. L. TÁRNOKY AND V. ANNE L. BREWS \\ From the Group Laboratory, Mile End Hospital, London
}

(RECEIVED FOR PUbliCATION MARCH 3, 1950)

The control of salicylate therapy by frequent estimation of the blood level requires a simple method suitable for use in a routine clinical laboratory. The method of Brodie. Udenfriend, and Coburn (1944) is generally accepted on account of its accuracy but is somewhat too laborious for a large number of estimations. A number of other methods are known but none has found general acceptance. Some of these were given preliminary trials in the summer of 1948 . They were the methods of Camponovo (1945, 1946), Barker (1936), Volterra and Jacobs (1947), Weichselbaum and Shapiro (1945), Coburn (1943), Mallick and Rehmann (1945), and Vélez-Orozco and Guerra (1946). Camponovo's $(1945,1946)$ method seemed the only satisfactory procedure. At the time this was available to us only in its abstracted form, and restandardization was necessary. A gradually evolved modified version has been in use in this laboratory for over a year. Comparing this with Camponovo's full papers shows a considerable difference in technique, our version being equally accurate but simpler.

\section{Experimental}

Principle.-Serum is added to acetone to precipitate proteins, dissolve salicylate without previous acidification and, possibly, free any salicylate held by protein. The drug is transferred to an aqueous-acetone phase by the addition of water and extraction with a second organic solvent. The salicylate content of this phase is determined by the well-known colour reaction with ferric chloride.

Reagents.-1. Acetone A.R.

2. Acetone, $15 \%(v / v)$ in water.

3. Methylene chloride (laboratory reagent quality).

4. Ferric chloride, stock solution, $20 \%(\mathrm{w} / \mathrm{v})$ in water.

5. Ferric chloride, working solution, $0.05 \%(\mathrm{w} / \mathrm{v})$. The working solution is made by diluting $0.25 \mathrm{ml}$. 4 to $100 \mathrm{ml}$. with water. When this reagent is read in the photoelectric colorimeter under the same conditions as a test solution, the reading should not exceed one division.

Method.-Serum $(1.0 \mathrm{ml}$.) is added slowly to $5.0 \mathrm{ml}$. acetone, preferably contained in a 4-in. "quickfit" test-tube fitted with a ground glass stopper. The tube is shaken vigorously for three minutes, allowed to stand for 20 minutes, and centrifuged at moderate speed for five minutes.

Clear supernatant liquid $(4.0 \mathrm{ml}$.) is added to a centrifuge tube containing $1.0 \mathrm{ml}$. methylene chloride and $3.0 \mathrm{ml} .0 .05 \%$ ferric chloride. The tube is shaken with inversion for one minute and centrifuged for five minutes. The purple upper layer is removed by means of a Pasteur pipette and compared with a standard solution, using 
a photoelectric colorimeter with medium size colorimeter tubes $(1 \mathrm{~cm}$. diam.), an Ilford 624 or 404 green filter, and setting the instrument to zero with a water blank. A Dubosq-type visual colorimeter can be used with standard 2. The colours may be read immediately and are stable for at least two hours. Too deeply coloured solutions are diluted with $15 \%$ acetone before reading.

Standards.-(1) Stock Standard Solution (200 mg. salicylic acid per $100 \mathrm{ml}$.).Sodium salicylate, $579.7 \mathrm{mg}$., is dissolved in $250 \mathrm{ml}$. water.

(2) Dilute Standard Solutions (20 and $40 \mathrm{mg}$. per $100 \mathrm{ml}$.).-These are prepared by diluting (1) accordingly. The dilute standard, $1.0 \mathrm{ml}$., is then treated in the same way as serum. This standard is suitable for use both with visual and photoelectric colorimeters.

(3) Simplified Dilute Standard Solution (for use with photoelectric colorimeter only).This is prepared by diluting $3.6 \mathrm{ml}$. of stock standard to $100 \mathrm{ml}$. with water $; 4.0 \mathrm{ml}$. of this mixed with $2.0 \mathrm{ml}$. $0.05 \%$ ferric chloride gives a solution equal in colour intensity (though not in colour) to that of a $40 \mathrm{mg}$. per $100 \mathrm{ml}$. standard solution.

All three solutions are preserved with chloroform and are stable for several months.

\section{Results}

The present method cannot be applied to whole blood. This is contrary to Camponovo, who describes his procedure as suitable for use with serum, plasma, or whole blood. Oxalated plasma is also unsuitable owing to the colour reaction between oxalate and ferric chloride. The use of the two solvents, however, permits of the analysis of haemolysed, pigmented, and lipoid sera. Camponovo records a yellowish tinge in the aqueous acetone extracts of some sera. This is overcome by adding $0.1 \mathrm{ml}$. saturated calcium chloride solution to the acetone used in the first extraction. In our experience this has not been necessary. No blank readings have been found with sera not containing salicylate.

Using Ilford 404 or, preferably, 624 filters, the colour intensities are proportional to concentration in the range between 5 and $100 \mathrm{mg}$. salicylic acid per $100 \mathrm{ml}$.

The colour obtained varies with the relative proportions of water and acetone in the medium. Solutions containing more water are bluer ; those containing more acetone, browner. In the conditions of the determination, methylene chloride reduces the volume of the coloured layer by $24 \%$, the removal of acetone giving a deeper and bluer solution. In both these respects methylene chloride is preferable to the chloroform used by Camponovo. Other solvents have been tried; these are carbon tetrachloride, ethylene chloride, benzene, toluene, xylene, 2-octanol, and ethyl acetate. Although the colour of the final aqueous solutions varies with these solvents, the colour intensity in most cases depends simply on the degree of concentration

TABLE

Recoveries of Salicylate (Stock Standard Solution) Added to Serum

\begin{tabular}{c|c|c|c}
\hline \multirow{2}{*}{$\begin{array}{c}\text { Serum Salicylic Acid } \\
\text { Level (mg./100 ml.) }\end{array}$} & No. of Experiments & Recovery (\%) \\
\cline { 2 - 3 } & & Range & Mean \\
\hline 20 & 33 & $87-92$ & 90 \\
40 & 13 & $91-96$ & 94 \\
\hline
\end{tabular}


achieved by the extraction. Benzene seems a suitable second solvent, provided the colorimeter tubes can be used for the second extraction and for centrifuging; the colours could then be read without separating the two layers.

Recoveries from serum are shown in the Table.

\section{Summary}

A method for estimating salicylate in serum has been evolved from Camponovo's $(1945,1946)$ double extraction procedure. The method is simple and well adapted for routine use. It requires serum (which may be haemolysed, pigmented, or lipoid) and should not be used with oxalated plasma or with whole blood.

\section{REFERENCES}

Barker, M. H. (1936). J. Amer. med. Ass., 106, 762. Compare Norris, R. F., Martens, V. E., and Sunderman, F. W. (1945). Amer. J. clin. Path., 15, 196.

Brodie, B. B., Udenfriend, S., and Coburn, A. F. (1944). J. Pharmacol., 80, 114.

Camponovo, P. B. (1945). Rev. Soc. argent. Biol., 21, 309. (1946). Rev. Soc. bioquim. argent., 13, 67.

Coburn, A. F. (1943). Bull. Johns Hopk. Hosp., 73, 435.

Mallick, S. M. K., and Rehmann, A. (1945). Ann. Biochem. exp. Med., 5, 97.

Vélez Orozco, F., and Guerra, F. (1946). Arch. Inst. Cardiol. Mex., 16, 131. (Abstract in Chem. Abstr. (1946), 40, $7261^{8}$.)

Volterra, M., and Jacobs, M. D. (1947). J. Lab. clin. Med., 32, 1282.

Weichselbaum, T. E., and Shapiro, I. (1945). Amer. J. clin. Path. Tech. Sect., 9, 42. 